\title{
Status and Integration of Education in Public and Private Upper-secondary Schools in three Southern Border Provinces
}

\author{
Pongsatean Luengalongkot \\ Graduate School of Public Administration, Burapha University, Thailand \\ (Email:pongsate@ hotmail.com)
}

\begin{abstract}
This research aims to: 1) examine the status of education management in both public and private upper-secondary schools in three southern border provinces of Thailand, and; 2) study appropriate methods of integrating education congruent with the community's identity in both public and private uppersecondary schools in the three southern border provinces of Thailand. The data were collected through in-depth interviews from 13 key informants and through a focus group of 29 key informants. Tools used to collect data for this research included: observation form, indepth interview form and focus group form.The data were analyzed using content analysis. The research results were as follows: 1) A clearer status of education management in both public and private upper-secondary schools in the three southern border provinces of Thailand. There are many responsible agencies that have been working on education management in these provinces, but the laws and other regulations in the field of education are not consistent with reality. In addition, the current situation of the problem in these provinces is a lack of encouragement for the teachers to work in the three provinces and some teachers do not teach the subject of his or her degree. The quality of education in ordinary courses in upper secondary schools of the three southern border provinces is at a low level. In addition, the proportion of students in private upper-secondary schools that provide religious education is higher than in public upper-secondary schools. 2) Appropriate methods of integrated education congruent with the community's identity in both public and private upper-secondary schools in the three southern border provinces were found. There are 4 methods of integration. First is the
\end{abstract}

integration of education management. It is necessary to establish a main agency to coordinate organizations related to education in the southern provinces and activities between administrators and teachers of Thai Muslims and Thai Buddhists should be promoted. In addition, there should be plans for cooperation between public and private schools for teaching Islamic studies and conducting an exchange of resources and materials for the teaching of Islamic studies. Second is integration of the budget. Allocation of budgets for private schools should consider the real situation of the schools. Third is integration of personnel management. There should be a program to train existing teachers who lack teaching experience and retired teachers which the ability to teach should be hired to alleviate the problem of lack of teachers and religious teachers from private schools can be invited to help teach religion in public schools. Finally is the integration of academic matters. To promote Islamic study, The Board of Basic Education should expand the intensive teaching of Islamic studies in public schools and development of the curriculum should promote the real and continuing integration of ordinary and religious courses.

Keywords: Integration, Education

\section{Introduction}

The three southern border provinces of Thailand have a variety of educational institutions such as universities, colleges, schools, and education centers in mosques. The government has built more public uppersecondary schools in the area, but most parents or guardians prefer to send their children to learn both general subjects and religion in 
Islamic institutions or private schools that provide Islamic religion, because public schools cannot provide adequate Islamic religion for use in daily life. A 2008 research study noted that 89 percent of the public attended public primary schools and 11 percent the private sector, yet in public uppersecondary schools, only 33 percent attended (based on The Office of Education, Ministry of Education, 2008). Nearly all government mandates have recognized and considered the importance and necessity of educational development in the three southern border provinces but the current situation of educational administration there, with its diverse attitudes towards quality and standards, learners lack the competency to compete for further educational opportunities. Students spend too much time learning content due to a shortage of integrated learning. In addition, the three southern border provinces have many specific issues such as the diversity of race, religion and language, as well as poverty and conflict that have had a significant impact on educational development. Therefore, educational administration in the three southern border provinces fails to consider the local identities, harmonies, desires, and lifestyles of most people. Besides this, there is unequal support for teachers in the public private school sectors. (SermSak Visalaporn, 2009)

Based on the data, it can be seen that the situation of educational administration in both public and private schools in the three southern border provinces is very important. This parallels The Educational Act, 1999, which defined the aims and principles of educational administration as to develop Thai people in order to be complete in physical appearance, mind, intellect and virtue along with morality. Chapter 4, section 23, specified that both formal and non-formal education must emphasize the importance of morality, including knowledge, and appropriate integration in each level of education. In addition, section 24 (4) stated the importance of "learning and teaching processes by integrating a variety of knowledge to balance proportional development of morality, values, and characteristics, that meet the aims of all majors". Therefore, the field of education and social sciences generally, has to be responsible for both religion and society. The principles of integrated education must be used in educational administration by linking knowledge with related experience, while maintaining a sense of community identity. The present context of the three southern border provinces requires that education be integrated without discrimination between education and way of life.

This study focused on education as a builder of a stronger community by integrating management of education with students' learning which will be beneficial to upper secondary school students in the southern provinces. This should lead to a higher level of education by maintaining students' identity and helping them to apply knowledge gained at a higher level to develop their own communities as well as the country. Therefore, The Office of the Secretariat of the Ministry of Education has assigned a researcher to study the status and integration of education in public and private upper-secondary schools in three southern border provinces. The result of this study of upper-secondary schools are very useful because it can benefit and strengthen education in both public and private schools at the uppersecondary school and higher levels.

\section{Objectives of the Research}

1) Examine the status of education management in both public and private uppersecondary schools in the three southern border provinces of Thailand.

2) Study appropriate methods of integrated education congruent with the community's identity in both public and private uppersecondary schools in the three southern border provinces of Thailand. 


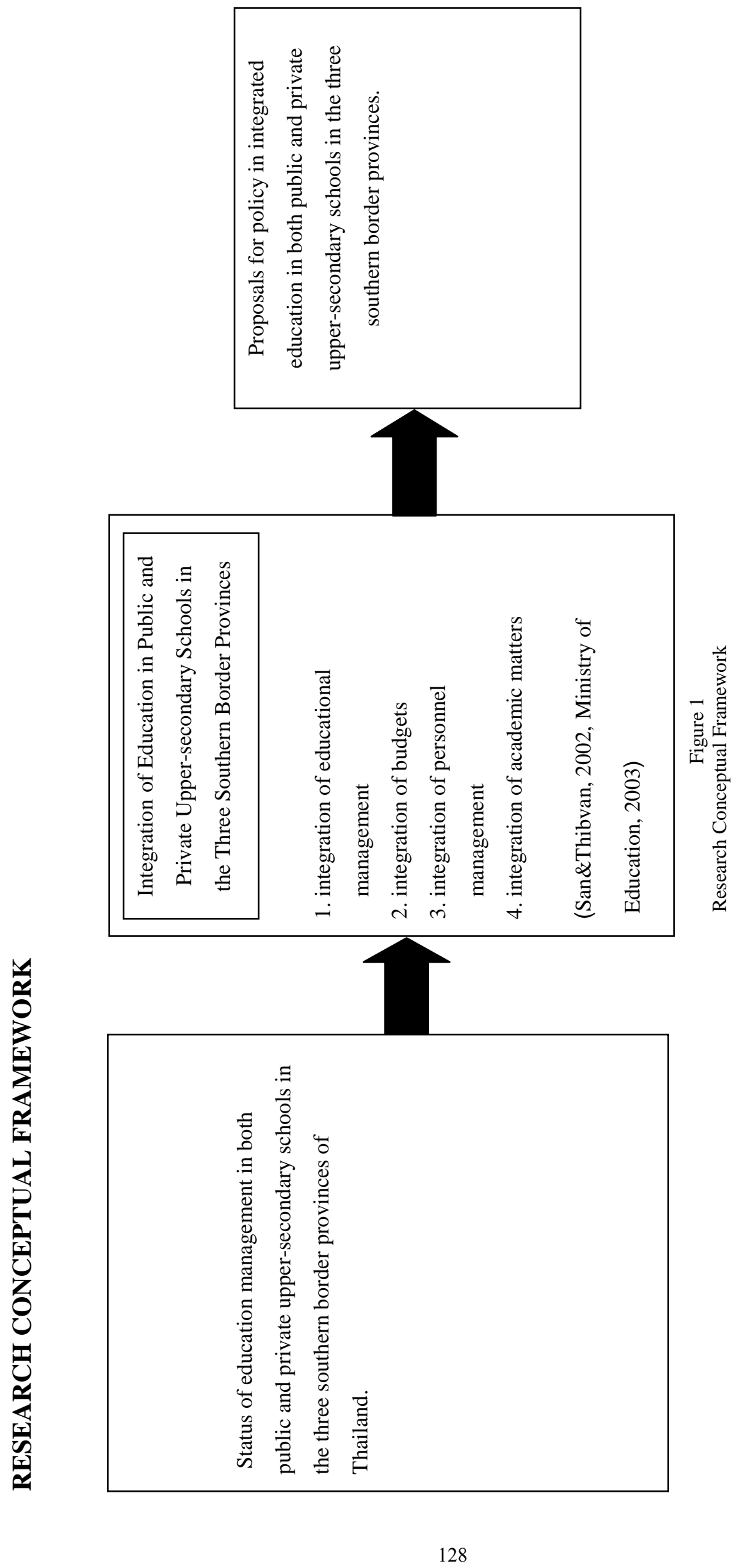




\section{Research Methodology}

This research is qualitative.

Population

Key informants

Primary data for in-depth interviews:

The data were collected through in-depth interviews with 13 key informants.

meetings:

Primary data for focus group

The data were collected through meetings with 29 key informants.

Research Tools

The researcher constructed the following tools to collect data for the research:

1. observation form

2. in-depth interview form

3. focus group form

Data Analysis

The Primary data were collected from observation of education integration projects, in-depth interviews and group focus sessions. The secondary data were collected from related documents. All data were analyzed using content analysis.

\section{Conclusion}

Status of education management in public and private upper-secondary school in three southern border provinces of Thailand.

1. There are many responsible agencies that have been working on education management in the three southern border provinces. The status of education management and administrative structure are in very good condition and well designed. Yet the process of application is still weak in performance. No responsible agency is working well with the others, and in addition they do not understand the true nature of the problems well; furthermore they are focusing on method rather than the goal and lack continuity in the work which leads to obstacles.

2. The majority of laws and other regulations in the field of education are very complex and not consistent with reality.

3. A serious problem in the three southern border provinces is the quality of the teachers. Throughout the interviews with Thai Muslims, it was found that firstly, teachers lack encouragement to work in the three provinces and secondly, that some teachers do not teach in the subject of his or her degree.
4. The quality of education in ordinary courses in upper secondary schools students of the three southern border provinces is at a low level. Education quality assessment results from 2009 found that the average score in all subjects of the students in the three southern border provinces is lower than the national average (NT) except in English. These results are in conformance with the results of the interviews which showed that the average score of students in all subjects is lower than the national average because teachers have little time to teach to the students and both teachers and students are under the supervision of the military. Some teachers have also found a lack of dedication in working with children while the students may have linguistic problems in communicating. (Office of the National Committee for Social and Economic Development, 2011)

5. The proportion of students in private schools that provide religious education is higher than in public schools. 30 percent are public and 70 percent are private.

Appropriate methods of integrated education congruent with the community's identity in both public and private upper-secondary schools in three southern border provinces of Thailand.

1. Integration of educational management

1.1 Having a variety of agencies to supervise and support the work application is a good policy that can ensure the unity of operations. To implement policy into practice, it is necessary to establish a main agency to coordinate related departments of education in the southern provinces. In addition, meetings should be arranged to convey important policies since it is more effective than the use of documents alone.

1.2 Promoting activities between administrators and teachers of Thai Muslims and Thai Buddhists should inform the appropriateness of objectives and detailed activities for cooperation. Furthermore, those responsible for cooperation must have an understanding of the two cultures, considering work coordination, placement and food preparation etc. These processes should be carefully constructed to avoid bias and avoid conflict of interests. Activities Muslims cannot do such as prostration and image-worship should not be held.

(Office of the National Committee for Social and Economic Development, 2011) 
1.3 Should plan for cooperation between public and private schools for teaching Islamic studies and conducting an exchange of resource and materials for the teaching of Islamic studies.

2. Integration of the budget

2.1 Allocation of budget for private schools should consider the real situation of the schools. In this case, there should be a clear division of type of schools such as ordinary private schools, religious private schools, and private schools founded by foundations. Appropriate teachers should be considered for the different needs of each type of school.

2.2 The process of budget allocation should be carried out by an independent committee arranged by the Board of Directors.

3. Integration of personnel management

3.1 There should be a program to develop existing teachers who lack teaching experience.

3.2 There retired teachers with the ability to teach should be hired to alleviate the problem of lack of teachers.

3.3 There religious teachers from private schools should be invited to help teach religion.

4. Integration of academic matters

4.1 To promote Islamic study, The Board of Basic Education should expand the intensive teaching of Islamic studies in public schools.

4.2. Development of the curriculum should promote the real and continuing integration of ordinary and religious courses.

\section{References}

[1] Hanson, Joanne Amelia. Integrating Children's Literature into the Upper
Elementary Social Studies Curriculum : The Japanese Internment During World War II. [On-line]. Master Dissertation, Simon Fraser University. ProQuestDissertation Abstracts. Abstract from: DAI 35/05, (1997, October). .

[2] Krejcie, Robert V. \& Morgan, Earyle W. Educational and Psychological Measurement. Minisota: Minisota University, 1970.

[3] Office of the National Committee for Social and Economic Development. Evaluation project for special development plan in special zone at southern border province of Thailand. Bangkok: Office of the National Committee for Social and Economic Development, 2011.

[4] San Vorn and Thib. Teacher training tool: Decentralization of Education. Bangkok, 2002.

[5] Serm Sak Visalaporn. Status of education management in southern border provinces of Thailand. Bangkok: Office of education of Ministry of Education, 2009.

[6] Office of education of Ministry of Education. The education development plan in special development zone at southern border provinces of Thailand 2552-2555. Bangkok: Office of education of Ministry of Education, 2008.

[7] Walter Floyd-Levin, Reulan. Perspectives from England on Using Integrated Curriculum : A Thematic Approach to Social Studies. Doctoral Dissertation, University of Kansas. ProQuestDissertation Abstracts. Abstract from: DAI-A 59-08, 1995, February. 